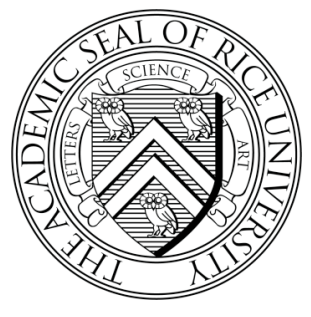

The James A. Baker III Institute for Public Policy

RICE UNIVERSITY

\title{
EFFECTS OF LOW-SKILLED IMMIGRATION ON U.S. NATIVES: EVIDENCE FROM HURRICANE MITCH
}

\author{
BY \\ Adriana KUGLER \\ UNIVERSITY OF HOUSTON, NBER, CEPR AND IZA \\ AND \\ MuTLu YusKeL \\ UNIVERSITY OF HOUSTON
}

JANUARY 2006 
THESE PAPERS WERE WRITTEN BY A RESEARCHER (OR RESEARCHERS) WHO PARTICIPATED IN A BAKER INSTITUTE RESEARCH PROJECT. WHEREVER FEASIBLE, THESE PAPERS ARE REVIEWED BY OUTSIDE EXPERTS BEFORE THEY ARE RELEASED. HOWEVER, THE RESEARCH AND VIEWS EXPRESSED IN THESE PAPERS ARE THOSE OF THE INDIVIDUAL RESEARCHER(S), AND DO NOT NECESSARILY REPRESENT THE VIEWS OF THE JAMES A. BAKER III INSTITUTE FOR PUBLIC POliCy. THIS BAKER INSTITUTE RESEARCH PAPER IS INTENDED TO MAKE RESUlTS OF BAKER INSTITUTE RESEARCH AVAILABLE TO OTHER RESEARCHERS IN PRELIMINARY FORM TO ENCOURAGE DISCUSSION AND SUGGESTIONS FOR REVISION BEFORE FINAL PUBLICATION.

(C) 2006 by the James A. Baker III Institute for Public Policy of Rice University

THIS MATERIAL MAY BE QUOTED OR REPRODUCED WITHOUT PRIOR PERMISSION, PROVIDED APPROPRIATE CREDIT IS GIVEN TO THE AUTHOR AND the James A. Baker III Institute for Public Policy. 


\title{
Effects of Low-Skilled Immigration on U.S. Natives: Evidence from Hurricane Mitch*
}

\author{
Adriana Kugler \\ University of Houston, NBER, CEPR and IZA \\ Mutlu Yuksel \\ University of Houston
}

January 27, 2006

\begin{abstract}
Starting in the 1980s, the composition of immigrants to the U.S. shifted towards less-skilled workers. Around this time, real wages and employment of younger and less-educated U.S. workers fell. Some believe that recent shifts in immigration may be partly responsible for the bad fortunes of unskilled workers in the U.S. On the other hand, low-skilled immigrants may complement relatively skilled natives. OLS estimates using Census data show that wages and employment are positively related to immigrant Latin American shares by state and year. However, these estimates are likely to be biased if immigrants move towards regions where there is high demand for their skills. An IV strategy, which exploits a large influx of Central American immigrants towards U.S. Southern ports of entry after Hurricane Mitch and who were quickly legalized, generates positive wage effects for College and High School-educated native men and women and earlier Latin American immigrant men but not for less-educated workers. These results are robust to controls for outmigration by earlier immigrants in response to recent Latin American immigration, suggesting that low-skilled immigrants complement high-skilled natives. We also find some evidence of negative employment effects on less educated natives when we control for potential out-migration, suggesting that recent immigrants may also substitute for less-skilled natives.
\end{abstract}

Keywords: Immigration, Rising Inequality, Skilled Premium, Employment Structure, Natural Experiments.

JEL Classification: J11, J21, J31, J61.

\footnotetext{
${ }^{*}$ We are especially grateful to Joshua Angrist and Peter Mieszkowski, and to Chinhui Juhn for useful comments. Adriana Kugler thanks the Baker Institute for financial support through a grant from the Houston Endowment. E-mail for correspondence: adkugler@uh.edu.
} 


\section{Introduction}

Since 1980, the composition of immigrants to the U.S. has shifted towards less skilled workers. Many believe the flow of unskilled immigrants has had a negative effect on the fortunes of unskilled natives in the labor market. However, previous work on the impact of immigration in the U.S. has generally found little evidence of earnings and employment effects on natives (e.g., Friedberg and Hunt, 1995). A crucial problem in assessing the impact of immigration is that immigrants may move precisely to areas where, or during times when, there is high demand for their skills. This makes it difficult to detect the effects of immigration on native labor market outcomes since natives may also benefit from positive demand shocks. To address this issue, a number of studies have used exogenous sources of immigration (e.g., Card (1990, 2001) for the U.S., Hunt (1992) for France, Carrington and deLima (1996) for Portugal, Angrist and Kugler (2001) for Europe). However, even these studies for the U.S. find modest or little impact of immigration on the wages and employment of less-skilled natives.

Given the dirt of evidence focusing on exogenously-driven immigration into the U.S., in this paper we revisit the question of the impact of immigration by exploiting the influx of Central American immigrants towards U.S. border states following Hurricane Mitch in October 1998. Like, the Mariel Boatlift studied by Card (1990), this natural experiment allows us to concentrate on exogenous immigration to the U.S. both in terms of timing and location. In addition, given the composition of Latin American immigrants towards younger and less educated workers, this quasi-experiment allows us to focus on the impact of unskilled immigrants who are perceived as the biggest threat in terms of worsening the labor market prospects of natives. Moreover, we control for state-specific trends to further address the concern that ongoing positive demand shocks in a state may be both attracting immigrants as well as improving labor market conditions for natives and all other workers in the state.

Using Census data for 1970-2000, we examine whether the influx of young and less educated immigrants who exogenously migrated from Latin America in the late 1990s affected the earnings and employment of natives in various skill groups. Our OLS results suggest Latin American immigration is positively related to native hourly wages and to a lesser extent to employment. However, as pointed out above, these estimates are likely to be biased if immigrants migrate towards states where, or during times when, there is high demand for their skills. IV estimates, relying on the influx of Latin American immigrants following Hurricane Mitch towards U.S. Southern ports of entry, show positive effects on the wages of College and High School educated native men and women and earlier Latin American 
immigrant men, after controlling for state-specific trends. Our results suggest that unskilled immigrants complement skilled native workers, possibly by taking up jobs (i.e., housekeeping, gardening, childcare) which allow skilled workers to increase their productivity.

Recent analyses (e.g., Borjas et al. (1997), Borjas (2003)) have argued that area studies, which mostly exploit regional variation in immigration, may be unreliable because they fail to account for two potentially countervailing responses to immigration. First, trade may counteract the effects of immigration on natives and, second, out-migration of natives may undo the effects of immigrants. The counteracting effects of inter-state trade are, however, likely to be a long-run phenomenon, while in this paper we are analyzing short-run effects. Since inter-state trade is unlikely to be a major concern in our context, we focus here on possible biases introduced due to internal migration responses to immigration.

While a number of previous studies have found little response of native and earlier immigrant migration to recent immigration (Card and DiNardo (2000), and Card (2001)), a recent study by Borjas (2005) finds that immigration is associated with lower in-migration, higher out-migration and lower population growth of natives. Here we examine whether the native population responded to the flow of immigrants following Hurricane Mitch and find no evidence that the native population adjusted in response to this wave of immigration. In addition, we explore whether earlier immigrants responded to recent Latin American immigration following Hurricane Mitch. We find that earlier Latin American, African, South Asian, and Middle Eastern immigrants did not respond to recent Latin American immigration by migrating less toward the South or by moving out of the Southern states. However, since earlier East Asian, European, and Australian immigrants appear to move away from Southern states in response to the recent wave of Latin American immigration, we control for possible out-migration by these group. Our results controlling for internal migration by earlier immigrants continue to show positive wage effects of Latin American immigration on College and High School educated native men, but now show no effects on the wages of native women or earlier Latin Americans. Results that control for migration responses by earlier immigrants also show some evidence of negative effects on the employment of less educated natives.

The rest of the paper is organized as follows. Section 2 documents Hurricane Mitch and its consequences in terms of migration towards U.S. Southern ports of entry. Section 3 describes our identification strategy, which exploits the exogenous influx of Central Americans to near-by U.S. states after Mitch. Section 4 describes the Census data used in the analysis. Section 5 presents estimates of immigration effects on native and earlier immigrant wages and employment. Section 6 concludes. 


\section{Consequences of Hurricane Mitch for Migration}

Similarly to a handful of other papers (e.g., Card (1991), Hunt (1992), Carrington and DeLima (1996), and Angrist and Kugler (2003)), in this paper we study the effects of an unexpected wave of immigrants on the labor market outcomes of natives and earlier immigrants. In particular, we exploit the immigration from Central America to the U.S. generated by a natural disaster, Hurricane Mitch. Other than Card (1991) ours is the only study for the U.S. based on a natural experiment as other studies of this sort exploit natural experiments in Europe. Like Card (1991), we are able to concentrate on unskilled immigrants, who are thought to contribute less to the host country and most likely to generate negative political reactions to immigration. ${ }^{1}$ In addition, since Hurricane Mitch generated immigration to a number of states and not only to a single city (like the Mariel boatlift which send immigrants only to Miami), we can exploit additional variation in immigration and we can control for ongoing trends in receiving states.

Another important difference between our study and Card's study of the Mariel boatlift is that, as described below, our study considers an influx of immigrants who quickly became legalized. By contrast, the Marielitos, unlike previous Cubans, were not given automatic refugee status and roughly half of them were initially sent to alien camps (Aguirre et. al. (1997)). While the Marielitos arrived to the U.S. between April and September of 1980, it was only until December 1984 that INS regulations were changed to allow Marielitos to register for permanent resident status. Moreover, both the wave of Cuban immigrants in 1980 and the wave of Central Americans after Mitch were composed mainly of less educated workers but the Mariel exodus included social 'undesirables', including some who had been in prison and others suffering from mental illnesses. While it is estimated that at most $7 \%$ of the 125,000 Cubans who arrived from the port of Mariel were social deviants, this wave of Cuban immigrants received very bad media coverage and many of them were subsequently institutionalized in the U.S. (Aguirre et. al. (1997)). In fact, public opinion polls from 1980 showed that $75 \%$ of respondents nationwide believed the Marielitos should had never been allowed into the U.S. and about $60 \%$ thought they should be sent back to Cuba (ABC News-Harris Survey (1980)). The perception of the Marielitos as undesirable, and possibly unemployable, contrasts with the image of Mitch refugees by the U.S. public, who were viewed as hard-working immigrants. The legal status of Mitch refugees and the positive perception of this wave of immigration means that Mitch immigrants were probably more likely to be hired and, thus, were more likely to compete with natives and earlier immigrants.

\footnotetext{
${ }^{1}$ See, for example, Borjas (1995) for a discussion of these issues.
} 
Hurricane Mitch hit Central America during the last week of October 1998. Honduras and Nicaragua were particularly hard hit, but Guatemala and El Salvador (and to a much lesser extent Belize) were also affected by the Hurricane (see the map in the Appendix). Hurricane Mitch became the fourth strongest Atlantic Hurricane on record together with Hurricanes Camille (1969), Allen (1980), and Gilbert (1988). It reached category 5 on the Saffir-Simpson scale with winds peaking at 180 miles per hour. Although Mitch was one of the strongest Atlantic hurricanes on record, the winds slowed down considerably as the storm moved inland. However, it was precisely the large amounts of rainfall that accumulated due to the slow moving storm that caused most of the damage. In fact, Mitch is the second deadliest hurricane to have hit the Atlantic after the Great Hurricane of 1780 (U.S. National Weather Service and U.K. National Meteorological Service).

Hurricane Mitch is estimated to have generated a very high human and material cost. Mitch is estimated to have caused 20,000 deaths and 13,000 injuries; to have left 1.5 million homeless, and to have affected another 2 million in other ways (FAO, 2001). The hurricane also destroyed a large part of these countries' road networks and social infrastructure, including hospitals and schools. Overall, FAO (2001) estimates that about 28,000 kilometers of roads and 160 bridges were destroyed. According to U.S. Aid, in El Salvador 60\% of the paved roads were damaged, and 300 schools and 22 health centers were destroyed or damaged by the hurricane (US Aid, 2004). In addition, Mitch largely destroyed these countries' crops and flooded agricultural land, reducing future production in the agricultural sector. The share of agriculture in the region's GDP dropped from $21.2 \%$ before the hurricane to $17.8 \%$ after Mitch (FAO, 2001). The direct estimated damage to the farming sector inflicted by Mitch was of $\$ 960.6$ million in Honduras, $\$ 264.1$ million in Guatemala, $\$ 129.8$ million in Nicaragua and $\$ 60.3$ million in El Salvador. Two of the crops most affected were bananas and coffee, on which these countries' export sector heavily depends on. According to ECLAC, the estimated damage totalled $\$ 6,18$ billion or about $12 \%$ of the Regional GDP, $42 \%$ of exports, $67 \%$ of gross fixed investment, and $34 \%$ of the external debt of these countries. Even before the hurricane hit, the four Central American countries most affected by the hurricane were already among the poorest countries in all of Latin America. For example, the percent of households living below the poverty line reached $73.8 \%, 65.1 \%, 53.5 \%$ and $48 \%$ in Honduras, Nicaragua, Guatemala, and El Salvador the year before the hurricane hit (ECLAC, 2001). Moreover, the hurricane hit the hardest in rural areas and, thus, is likely to have affected mainly individuals already living under or close to the poverty line.

According to the World Bank, the main way in which Central American men responded 
to the disaster was by migrating North (World Bank, 2001). ${ }^{2}$ According to information from Migration Departments in these countries, external migration from Honduras almost tripled and external migration from Nicaragua increased by about 40\% (FAO, 2001). In January 1999, Reuters and the New York Times headlines announced "Desperate Hurricane Survivors Push[ing] North to [the] U.S. Border." In January 1999, Honduran immigration director reported that about 300 Hondurans a day were leaving for the U.S. and visa requests for the U.S. were up $40 \%$ from the previous year. According to journalistic accounts many Central Americans crossed through Mexico to get to the U.S., which is reflected by the big rise in the "other than Mexican" apprehensions in the U.S.-Mexico border, which were close to 4,000 in January 1999 (i.e., a record high for a single month). Officials at the border in Brownsville, Texas area reported a $61 \%$ increase in the number of Hondurans apprehended after illegally crossing the border during the last three months of 1998. Likewise, in the Laredo, Texas area 583 "other than Mexican" foreigners were apprehended in December 1998 compared to 123 in December 1997. These figures illustrate the increase in Central American immigration after the natural disaster towards the Southern states of Texas, Florida and California, which had traditionally received this group of immigrants before the Hurricane (see map in the Appendix).

As a formal response to the migration generated by Hurricane Mitch, on December 30, 1998, the Immigration and Naturalization Service (INS) announced in a news release the designation of Temporary Protected Status (TPS) for Honduras and Nicaragua for a period of 18 months (i.e., through July 5, 2000). ${ }^{3}$ During the following 18th month period, Hondurans and Nicaraguans who had entered the country before this date would not be subject to removal and would be eligible for permission to work in the U.S. It is estimated that by 2003, close to 150,000 Hondurans and Nicaraguans had been granted Temporary Protected Status (TPS) to allow them to stay and work in the U.S. In addition, in the same news report, the INS announced that it would suspend deportations of Guatemalans and Salvadorans for 60 days (or until March 1999).

In the following section, we describe how we exploit the immigration at the end of 1998/beginning of 1999 towards U.S. Southern ports of entry from Central America following Hurricane Mitch to study the labor market effects of immigration on natives and earlier immigrants.

\footnotetext{
${ }^{2}$ By contrast, according to the study, women responded by increasing their labor force participation and mobilizing social networks.

${ }^{3}$ Up until that point, TPS had normally been granted to refugees from countries suffering from war or civil unrest, including: Bosnia, Burundi, Kosovo, Liberia, Monserrat, Sierra Leone, Somalia and Sudan.
} 


\section{Identification Strategy}

The goal of this paper is to identify the impact of less-skilled immigration on the wages and employment of natives and earlier immigrants. To do so, we begin with the following simple model:

$$
y_{i j t}=\mu_{j}+\tau_{t}+X_{i j t}^{\prime} \beta+\gamma S_{L A j t}+\varepsilon_{i j t},
$$

where the dependent variable, $y_{i j t}$, is either the log of the hourly wage or the employment status for individual $i$ in state $j$ at time $t$. The model includes state and year effects, $\mu_{j}$ and $\tau_{t}$. $X_{i j t}^{\prime}$ is a vector of individual characteristics of individual $i$ in state $j$ at time $t$, which includes education, experience, marital status, race, and occupation and industry dummies. ${ }^{4}$ The regressor $S_{L A j t}$ is the share of Latin American-born individuals who immigrated to state $j$ in the past five years out of the population in that state. ${ }^{5}$ This specification is estimated for male and female workers in three education groups (High School dropouts, High School graduates, and College educated). In addition, we estimate this same specification for earlier Latin-American and non-Latin American immigrants, where we classify earlier immigrants as foreign-born individuals who arrived more than 5 years ago. The idea of estimating this specification separately by education group is that some groups of workers may be more substitutable with recent Latin American immigrants than others.

A basic problem with this simple OLS regression is that the error term, $\varepsilon_{i j t}$, may be capturing a positive demand shock to state $j$ at time $t$, which could be driving the decisions of recent immigrants to move to that state at that point in time and which could also be affecting the wages and employment of natives and earlier immigrants. Overall positive demand shocks correlated with immigration will bias upwards the impact of immigration and may not allow us to detect any effects even if immigrants indeed reduce the wages and employment of natives and earlier immigrants. On the other hand, positive demand shocks to unskilled relative to skilled workers, which attract unskilled immigrants will bias upwards the effects of immigration on unskilled natives and earlier immigrants but will bias downwards the effects on skilled workers.

\footnotetext{
${ }^{4} \mathrm{By}$ controlling for these variables in the regression, we are able to control for potential changes in composition affecting the wages and employment of natives and earlier immigrants. Our controls are the same as those by Card (2001). Our results are, however, similar if we exclude controls for industry and occupation.

${ }^{5}$ As described below, we also tried using alternative regressors, including the shares of recent unskilled immigrants from Latin America and from all destinations. Using the share of unskilled immigrants instead of the share of Latin American immigrants yields similar but bigger effects.
} 
We address the potential endogeneity of immigration in two ways. First, we use an IV strategy which relies on the large influx of Central American immigrants towards close-by U.S. states following Hurricane Mitch. The first-stage equation for the IV estimates is:

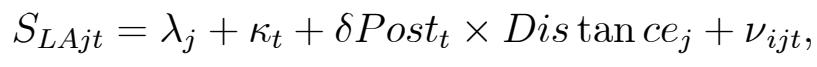

where $\lambda_{j}$ and $\kappa_{t}$ are state and year effects. Post $t_{t}$ is a dummy that takes the value of 1 if the immigrants arrived after Hurricane Mitch and zero otherwise, and Distan $c_{j}$ is a variable which measures crow miles from the capital of Honduras, Tegucigalpa, to the Southernmost city of each state $j .{ }^{6}$ The choice of instrument as the interaction between a post-Mitch dummy and distance from Tegucigalpa to various states in the U.S. is motivated by the discussion in the previous section which documents the large migration North from Central America towards near-by U.S. states right after Hurricane Mitch. Given that the Post dummy takes the value of 1 if the person is observed in the 2000 Census and zero otherwise and that the left-hand side variable includes Latin American immigrants who came in the past five years, our instrument captures those Latin Americans who came between 1995 and 2000 to states close-by to Tegucigalpa. ${ }^{7}$

As a specification check, we also estimate equivalent first stages for the share of earlier African, East Asian, South Asian, Middle Eastern, European, and Australian immigrants. The idea is that by estimating the first stage for other ethnic groups, we can check whether we are likely to be capturing Latin American immigration to the border states driven by Mitch or simply a generalized immigration pattern by all ethnic groups to border states in recent years.

\footnotetext{
${ }^{6}$ The Post $_{t}$ dummy takes the value of 1 if the person is observed in the 2000 Census and zero otherwise. Consequently, given that the left-hand side variable includes Latin American immigrants who came in the past five years, our instrument captures those Latin Americans who came in the past five years to states close-by to Tegucigalpa. We have also tried using the share who came in the last three years, which can be identified in the 1990 and 2000 Censuses and the results are very similar. For more details on the distance measure, see Table A1 in the Data Appendix. This table also shows the distance from the capital cities of the other affected Central American countries and the average distance from all four capital cities. The correlation between the distance from Tegucigalpa and the average distance from all four capital cities is 0.98. Our results below are robust to the use of this alternative measure.

${ }^{7}$ We also tried using the share who came in the last three years, which can only be identified in the 1997 and 2000 Censuses, so that our instrument would be capturing Latin Americans who came bewteen 1997 and 2000 in states close-by to Tegucigalpa. The results using the shares of those who came in the past three years provide an even stronger first stage, but we would loose information fromt eh 1970 and 1980 Censuses. The 1970 and 1980 Censuses ask the question of when the person came to live in the U.S. in 5-year intervals (e.g., 1965 to 1970, 1975 to 1980, etc.). By constrast, the 1990 Census asks the same question in three-year intervals (e.g., 1987 to 1990, etc) while the 2000 Census asks the exact year when the person came to lvie in the U.S.
} 
As a second way to control for the possibility that pre-existing demand shocks were driving Latin American immigration towards border states, we estimate specifications with state-type specific trends, where states are classified into far-away and close-by states according to whether they are above or below the median distance from Tegucigalpa. The specifications with trends replace $\lambda_{j}$ with $\lambda_{0 j}+\lambda_{1 j} t$ in the first stage and $\mu_{j}$ with $\mu_{0 j}+\mu_{1 j} t$ in the second stage. ${ }^{8}$

\section{Data Description}

Our data come from the U.S. Micro Census for the years 1970, 1980, 1990, and 2000. Census data has information on demographic characteristics including age, marital status, race, and education. We use the information on education and graduation to separate the sample into three groups of individuals: drop-outs, High School graduates, and College educated. ${ }^{9}$ More importantly for our study, the Census has precise information on country of birth which allows us to identify natives and foreign-born individuals or immigrants. In addition, the data allows us to distinguish immigrants from different origins as well as recent from earlier immigrants by using information on year since immigration to the U.S., where we define recent immigrants as those who arrived less than five years ago. ${ }^{10}$ We restrict our sample to individuals between 16 and 65 years of age. In addition, we exclude individuals working in the public sector.

The data also include information on labor market outcomes for the year just prior to the Census year. ${ }^{11}$ We use information on total hourly earnings together with information on weeks worked and hours per week to construct an hourly wage measure. These hourly wages are then deflated using a yearly CPI from the Bureau of Labor Statistics. ${ }^{12}$ We also construct an employment status indicator which takes the value of 1 if the person is employed and zero otherwise. The data also includes information on sector of employment and occupation at the 3-digit level, which are used to generate 1-digit industry and occupation codes on a uniform basis. ${ }^{13}$ Since information on labor market experience and tenure is not asked in

\footnotetext{
${ }^{8}$ As an alternative to control for state-sepcific trends, we included an interaction of distance with the trend. The results for natives reported below are robust to this specification.

${ }^{9}$ See Data Appendix for greater detail on how we divided individuals into these three education groups.

${ }^{10}$ We do not use information from the 1960 Census because data for this year does not include information on year since arrival to the U.S.

${ }^{11}$ Note that given that the influx of Central Americans following Mitch occurred in late 1998 and early 1999, using data on Labor Market outcomes from the 2000 Census implies that we will capture short-run effects of immigration, which should be stronger than the medium- and long-run effects.

${ }^{12}$ See the Data Appendix for more details on the construction of the hourly wage.

${ }^{13}$ See Data Appendix for more detail.
} 
the Census, we construct a measure of potential experience as age minus years of education minus 6 .

Table 1.A presents descriptive statistics for natives by education group (dropouts, High School graduates, and College educated) and sex. The table shows higher hourly wages and employment for more highly educated groups and for men than for women. The table also shows that individuals with more education are older; more likely to be married; and less likely to be in blue-collar occupations, and in the agricultural, construction and manufacturing sectors. Finally, the table shows that dropouts are disproportionately Black and Hispanic.

Table 1.B presents descriptive statistics for recent (i.e., those who arrived less than five years ago) and earlier (those who arrived more than five years ago) Latin American immigrants as well as for recent and earlier non-Latin American veteran immigrants. Immigrants from non-Latin American countries have on average completed High School, i.e., recent and earlier non-Latin American immigrants have completed 12.7 and 12.5 years of schooling on average. By contrast, Latin American immigrants are closer in educational attainment to native dropouts. Recent Latin American immigrants have on average 9.3 years of schooling and earlier Latin American immigrants have on average 10 years of schooling, compared with close to 9 years for native dropouts. Also like native dropouts, Latin American immigrants and, in particular, recent Latin American immigrants are more likely to work in blue-collar occupations and in agriculture, construction and manufacturing than more educated natives.

\section{$5 \quad$ Estimates of Immigration Effects}

\subsection{OLS Estimates}

Table 2 presents OLS estimates of the effect of immigration, i.e., $\gamma$ in equation (1). The dependent variables are the log of the hourly wage and an indicator of whether the person is employed or not. The controls are state and year effects; years of education; potential experience and potential experience squared; a marriage dummy; Black, Asian, and Hispanic dummies; and industry and occupation dummies at the 1-digit level. The reported standard

errors allow for clustering by state, allowing for correlations of individuals within states and for correlations within states over time.

Panel A of Table 2 shows the effects of immigration on male and female natives in different education groups. The results show positive effects of immigration on the hourly wages of women at all education levels and on the hourly wages of High School and College educated men. On the other hand, the results show no effect on male or female employment. Panels 
$\mathrm{B}$ and $\mathrm{C}$ show similar effects of recent immigrants on earlier immigrants. The results again suggest positive effects on the hourly wages of non-Latin American earlier immigrants as well as on the hourly wages of earlier immigrants from Latin America. Surprisingly, the results suggest that even the hourly wages of earlier immigrants who dropped out of school increased in immigrant receiving states. Also, the results suggest that employment increased for male and female earlier immigrants in immigrant-receiving states, with significant effects even on male dropouts. However, one may be suspicious of these results, since dropouts and immigrants seem to have about the same skill level and thus likely to be substitutes.

Given the potential response of immigration to positive regional demand shocks, which would also increase wages and employment for natives and earlier immigrants, it is difficult to give a causal interpretation to the OLS estimates. As discussed above, endogenous immigration in response to omitted regional demand shocks would introduce a positive biases in OLS estimates and may hide the true effects of immigration. On the other hand, endogenous immigration in response to demand shocks for unskilled relative to skilled workers may introduce negative biases in the OLS estimates for skilled workers. The following IV estimates based on exogenous immigration from Central America after Hurricane Mitch attempt to eliminate such biases.

\subsection{Estimates}

This Section presents estimates of immigration effects which rely on an IV strategy. The IV strategy is motivated by the large influx of Central American immigrants into close-by U.S. states in the late 1990s documented in Section 2. The description suggests that many immigrants were coming through Mexico and locating in states close to the border, suggesting that distance from the countries hard-hit by the hurricane should be a good predictor of the state share of Latin American immigrants after 1998. The first-stage equation for the IV estimates is given by equation (2). The essence of this IV strategy is to look for a break after Hurricane Mitch in hourly wages and employment in states close-by to Central America.

Table 3 presents results from estimating equation (2). Panel A which presents results without trends indicate that states closer to Tegucigalpa experienced an increase in the share of Latin American immigrants after Hurricane Mitch. In Panel B, we include state-specific trends to check whether the increase in the share of Latin American immigrants in closeby states simply reflects an ongoing trend or whether there is indeed a discernible break after Mitch. ${ }^{14}$ The results which include trends show an even bigger increase in the share

\footnotetext{
${ }^{14}$ We include separate trends for states closer and farther from Central America, where we divide the two groups according to whether their distance is less or more than the median distance from Tegucigalpa. The
} 
of Latin American immigrants after Mitch than the results without trends. ${ }^{15}$ In particular, the results with trends suggest that moving closer to Tegucigalpa from Washington State to Texas increases the share of immigrants coming from Latin America after Mitch by a third of a percentage point. ${ }^{16}$

To test whether the increase in the share of Latin American immigrants after the hurricane simply reflected a general increase in immigration towards Southern states towards the late 1990s not driven by the natural disaster, we also estimate the equivalent first stage regression for the shares of immigrants coming from: Africa, East Asia, South Asia, the Middle East, Europe, and Australia. Unlike the share of Latin American immigrants, the shares of immigrants from other destinations towards Southern states did not increase after Hurricane Mitch. The results with and without trends in Panels A and B show no effects on the immigration shares of other ethnic groups.

Table 4 reports results of equation (1) estimated for natives, but where the Latin American share is instrumented with the post-Mitch dummy and distance interaction. Panel A shows results for hourly wages and Panel B shows results for employment. As before the results show no effect on employment. On the other hand, the IV results continue to show an increase in the hourly wages for High School and College educated men with or without state-specific trends. The results without trends show no effects on the hourly wage of women, but the results with trends show a positive effect on the hourly wage of High School and College educated women. Unlike the OLS results, the IV results suggest no effect on the hourly wage of female dropouts who are more likely to be substitutes with immigrants. The results for men suggest an increase of between $6.3 \%$ and $8 \%$ in the men's hourly wage, while the results for women suggest an increase of between $3 \%$ and $4.4 \%$ in the women's hourly wage. These results suggest that less educated Latin American immigrants complement high-skilled natives. By contrast, these results would seem to suggest that Latin American immigrants do not displace native dropouts, though these results contrast with the results in the next section which control for internal migration responses by earlier immigrants.

Tables 5 and 6 present equivalent results to those in Table 4, but for earlier Latin American and non-Latin American immigrants. The results for earlier Latin American immigrants

inclusion of these trends provides a falsification test a-la Angrist and Krueger (1999), where they look at the impact of a false Mariel Boatlift in 1994 (an announcement by then-President Clinton to let Cuban Refugees into the U.S. but which never materialized) on the Miami labor market.

${ }^{15}$ The share of Latin Americans includes immigrants from Central America, South America, the Caribbean and Mexico. The first stage and other results are robust to the exclusion of Mexicans.

${ }^{16}$ We also tried estimating first stage regressions of the share of unskilled immigrants from all destinations and the share of unskilled immigrants from Latin America and the first-stage results are slightly smaller but significant, i.e., -0.0016(0.00076) and -0.001 (0.00046), respectively. By contrast, as pointed out above, the second stage results are similar but larger in magnitude. 
in Table 5 now suggest positive Latin American immigration effects on the hourly wages of High-school and College educated earlier Latin American immigrants, but no effects on dropouts or women in contrast to the OLS results. The results imply that an increase of $1 \%$ in the Latin American immigrant share would increase hourly wages by $5 \%$. Results without trends show no effects on the employment of earlier Latin American immigrants. When trends are added, there are no effects on any of the groups with the exception of a positive employment effect on dropout males. However, this effect disappears when controlling for internal migration responses in the next section.

Contrary to the OLS results in Table 2, the IV results with trends in Table 6 show no effects of Latin American immigration either on the hourly wages or on the employment of earlier non-Latin American immigrants. Thus, any positive effects on wages and employment observed in the OLS results seemed to have been largely driven by positive employment trends of previous immigrants in Southern states.

\subsection{Controlling for Migration Responses by Natives and Earlier Immigrants}

Aside from the problem of endogeneity which is addressed in the previous results by instrumenting the immigrant share, there are two additional potential biases in the results presented above. First, inter-state trade in response to lower wages from migration may dissipate the effects of immigration in the long-run. Second, out-migration by natives or earlier immigration may undo the effects of recent immigration. As the first effect is likely to be a long-run effect and, in this paper, we are studying short-run effects of immigration, we are mainly concerned here with the second potential problem.

Previous studies which examine the migration response of natives and earlier immigrants to recent immigration provide mixed evidence. For instance, Card (2001) estimates the effect of recent immigrants on net population growth, the outflow rate and the inflow rate of natives and earlier immigrants. On net, Card (2001) finds that immigration is associated with an increase in population growth for natives and a decrease for earlier immigrants, though the latter depends on whether weights are used or not for the analysis. The net effects are the result of effects on outflows and inflows of natives and earlier immigrants. In particular, recent immigration is associated with an increase in the outflow rate of natives and earlier immigrants, though the effect is small in magnitude especially for natives. At the same time, Card's study finds that recent immigration is associated with an increase in the inflow rate of natives and earlier immigrants, with the exception of the unweighted results for earlier immigrants. Card (2001) thus concludes that recent immigrant inflows may be correlated 
with positive demand shocks, which cause an increase in the net population of both natives and earlier immigrants. By contrast, the recent study by Borjas (2005) uses data from the 1960-2000 decennial censuses and finds that immigration is associated with a decline in the population growth rate of natives, which may mitigate the effects of immigration. This effect on net migration arises both because of higher out-migration and lower in-migration into high immigration states. He also finds that these associations become smaller as the geographic area that defines the labor market becomes larger. For example, moving from the metropolitan area level to the state level reduces the extent of these correlations. ${ }^{17}$ Borjas (2005), however, does not look at the association between recent immigration and migration patterns of earlier immigrants.

In Table 7 we explore whether net migration responded to exogenously driven Latin American immigration. In particular, Table 7 reports results of equations like equation (2), but where the dependent variable is the share of natives and earlier immigrants in the states' population. If natives and earlier immigrants respond to recent immigration by moving away from or slowing down migration towards states close to Central America, then we should expect a positive coefficient in the interaction term. By contrast, if native and earlier immigrant migration do not respond to the exogenously-generated Latin American immigration, then we should expect this coefficient to be insignificant. The results show no effect on natives or earlier Latin American immigrants. Moreover, the results show no effects of exogenously-generated recent Latin American immigration on the shares of earlier African, South Asian or Middle Eastern immigrants. On the other hand, there are positive effects on the shares of East Asian, European and Australian immigrants, suggesting that these groups may had responded by moving away from border states after Hurricane Mitch.

We deal with the possible concern that these groups of earlier immigrants may be counteracting the impact of earlier immigrants by re-estimating the IV results with trends, but adding the shares for the three immigrant groups of concern as follows:

$$
y_{i j t}=\mu_{0 j}+\mu_{1 j} t+\tau_{t}+X_{i j t}^{\prime} \beta+\gamma_{L A} S_{L A j t}+\gamma_{E A} S_{E A j t}+\gamma_{E U R} S_{E U R j t}+\gamma_{A U S} S_{A U S j t}+\varepsilon_{i j t},
$$

where $S_{E A j t}, S_{E U R j t}$, and $S_{A U S j t}$ are the shares of earlier East Asians, Europeans and Australians in the population, and where we instrument these shares with the lagged shares for these groups. Like in Card (2001), the use of these instruments is motivated by the fact that immigrants may prefer to locate in places where previous immigrants from their same

\footnotetext{
${ }^{17}$ Thus, to the extent that we use state-level rather than metropolitan-level immigration, internal migration in response to immigration should be less of a concern in our study.
} 
ethnicity provide them access to social networks and facilitate entry into labor and housing markets.

Tables 8 and 9 report results for hourly wages and employment of natives and earlier Latin American immigrants, respectively. The results in Table 8 show smaller but positive effects of Latin American immigration on educated native men than those found in Table 4. In particular, the results show that a $1 \%$ increase in the Latin American share increases the wages of skilled native men by between 5-6\%. By contrast, the positive wage effects for women are now insignificant. Moreover, the results now show negative employment effects of Latin American immigration on less skilled men and women. For example, a 0.10 inflow rate of new Latin American immigrants would be expected to depress the employment rate of less-educated natives by a 0.5 percentage point. ${ }^{18}$ Thus, the results controlling for potential out-migration by other groups suggest not only positive wage effects on skilled workers, but also displacement of less skilled natives by recent Latin American immigrants. By contrast, Table 9 shows that both wage and employment effects of recent Latin American immigration disappear when controlling for internal migration responses by other ethnic groups. ${ }^{19}$

\section{Conclusion}

This paper presents new evidence on the impact of less-skilled Latin American immigration on the wages and employment of natives and earlier immigrants in the U.S. OLS estimates show positive wage and employment effects of Latin American immigration on both natives and earlier immigrants. However, IV estimates, which exploit immigration from Central America to close-by U.S. states following Hurricane Mitch, suggest that less skilled immigration increases the wages of skilled natives and earlier Latin American migrants but have no effect on employment. Moreover, when we control for internal migration responses by earlier immigrants, we continue to find that recent Latin American immigration generates positive wage effects on skilled natives, but we now find no effects on earlier Latin immigrants. In addition, unlike the results without controls for earlier immigration, we now find some evidence of negative employment effects on less skilled natives. However, given that our instruments for the earlier immigrant shares are not as convincing as those for the recent Latin American immigrant share, we interpret these latter results with care.

The results here thus indicate that while highly skilled natives benefit from recent immigration by getting higher wages, less skilled natives are displaced by recent immigration

\footnotetext{
${ }^{18}$ The magnitude of this effect is about half of the employment effect found by Card (2001).

${ }^{19}$ Although, we cannot re-estimate the effects for earlier non-Latin American immigrants, our findings in Table 7 suggest that the results in Table 6 are likely to be biased upwards.
} 
of low educated workers who can easily substitute them. The positive wage effects of immigration on skilled natives are consistent with theory which predicts that natives benefit from immigration mainly because of complementarities in production and that these benefits are larger when immigrants are sufficiently different from natives (Borjas (1995) and Ottaviano and Peri (2005)). The results are also consistent with evidence by Ottaviano and Peri (2005) and Schoeni (1996) showing a positive impact of immigration on average native wages across U.S. metropolitan areas. Moreover, we find some evidence of negative employment effects for less-skilled natives, which are similar, though smaller in magnitude, to those found by Card (2001). Our analysis thus highlights the importance of considering not only the costs of immigration, but also the potential benefits from immigration when considering immigration-related policies. 


\section{Data Appendix}

\section{Census Data}

We use the $1 \%$ publicly available random sample from the U.S. Censuses for the years 1970, 1980, 1990, and 2000. We do not use 1960 because in this year, the Census did not ask year since arrival to the U.S., so that we are unable to separate recent from earlier immigrants.

\section{Hourly Wages}

To construct our hourly wage measure, we divide the yearly earnings by average weeks worked per year and average hours worked per week. Since the information on annual earnings is top-coded using different amounts for every year, we instead use a uniform criteria and we top code at the 99th percentile for all years and eliminate those observations whose yearly earnings are above the 99th percentile for each year. Also, while for 1980, 1990, and 2000 we have information on the exact average number of weeks and hours worked per week, the 1970 Census instead provides six 13-week intervals (e.g., 1-13, 14-26, etc.) and eight 14-hour intervals (e.g., 1-14, 15-29, etc.) for the average number of weeks and hours worked, respectively. For 1970, we thus use the mid-point in the interval reported (e.g., 7 weeks if the individual reported to have average weeks worked between 1-13 weeks).

\section{Education Groups}

Individuals were divided into three education groups: dropouts, High School graduates and College educated. We constructed these groups using information on years of education as well as information on whether individuals earned a degree. The year of education variable puts the person into one of 9 categories: no school or preschool; grades 1-4; grade 5-8; grade 9 , grade 10 , grade 11 , grade $12 ; 1-3$ years of college, more than 4 years of college. For the first three groups we assign 0,3 , and 7 years of schooling, while for the last two categories we assign 14 and 16 years of schooling. To identify dropouts from High School graduates we use information on whether the individual earned a degree. Thus, a person with 12 years of schooling but who has not earned a degree is classified as a dropout, while those with 12 years of schooling and who have earned a degree are classified as High School graduates.

\section{Classification of Industries and Occupations}

The Census includes 3-digit SIC codes for industries and occupations. In our analysis, we use these 3-digit codes to reclassify industries on a consistent basis at the 1-digit level. Industries are reclassified into ten categories: agriculture; mining; construction; manufacturing; wholesale and retail trade; transportation, utilities, information and communications; FIRE; professional education; arts; and personal services. Occupations are reclassified into 6 categories: managerial and professional; technical, sales and administrative support; ser- 
vice; farming, forestry and fishing; precision production, craft, and repair; and operators, fabricators, and laborers.

\section{CPI Data}

The consumer price index (CPI) comes from the Bureau of Labor Statistics. The average CPI is 38.8 for 1970; 82.4 for 1980; 130.7 for 1990; and 172.2 for 2000.

\section{Distance Information}

Our distance variable measures straight-line miles from the capital of Honduras, Tegucigalpa, to the Southernmost city in each state. Appendix Table A.1 reports the distance from Tegucigalpa to each states' Southern-most city, which is the distance measure we use in our analysis. The table also reports the distance from the capitals of Nicaragua, Guatemala and El Salvador: Managua, Guatemala City and San Salvador. The correlation between the distance from Tegucigalpa and an alternative measure which gives average crow miles from all the capital cities is 0.998 . 


\section{References}

[1] Altonji, Joseph and David Card. 1991. "The Effects of Immigration on the Labor Market Outcomes of Less-Skilled Natives," in John Abowd and Richard Freeman, eds., Immigration, Trade and Labor. Chicago: Chicago University Press.

[2] Angrist, Joshua and Alan Krueger. 1999. "Empirical Strategies in Labor Economics," in Orley Ashenfelter and David Card, eds., Handbook of Labor Economics, Vol.3A. Amsterdam, New York and Oxford: Elsevier Science, North-Holland.

[3] Angrist, Joshua and Adriana Kugler. 2003. "Protective or Counter-Productive? Labour Market Institutions and the Effect of Immigration on EU Natives," Economic Journal, 113: F302-F331.

[4] Borjas, George. 2005. "Native Internal Migration and the Labor Market Impact of Immigration," NBER Working Paper No. 11610.

[5] Borjas, George. 2003. "The Labor Demand Curve is Downward Sloping: Reexamining the Impact of Immigration on the Labor Market," Quarterly Journal of Economics, 118(4): 1335-1374.

[6] Borjas, George. 2002. "Assimilation, Changes in Cohort Quality, and the Earnings of Immigrants," in Klaus Zimmerman and T. Bauer, eds., The Economics of Migration: Assimilation of Migrants. Sheltenham , U.K. and Northampton, Mass.: Elgar.

[7] Borjas, George. 1995. "The Economic Benefits from Immigration," Journal of Economic Perspectives, 9: 3-22.

[8] Borjas, George, Richard Freeman and Lawrence Katz. 1997. "How Much Do Immigration and Trade Affect Labor Market Outcomes?," Brookings Papers on Economic Activity, 0(1): 1-67.

[9] Card, David. 2001. "Immigrant Flows, Native Outflows, and the Local Labor Market Impacts of Higher Immigration," Journal of Labor Economics, 19(1): 22-64.

[10] Card, David. 1990. "The Impact of the Mariel Boatlift on the Miami Labor Market," Industrial and Labor Relations Review, 43: 245-257.

[11] Card, David and John DiNardo. 2000. "Do Immigrant Inflows Lead to Native Outflows?," American Economic Review, 90(2): 360-367. 
[12] Carrington, William and DeLima, Pedro. 1996. "The Impact of 1970s Repatriates from Africa on the Portuguese Labor Market," Industrial and Labor Relations Review, 49: 330-347.

[13] Food and Agriculture Organization of the United Nations (FAO). 2001. Analysis of the Medium-term Effects of Hurricane Mitch on Food Security in Central America. Rome: FAO.

[14] Friedberg, Rachel and Jennifer Hunt. 1995. "The Impact of Immigrants on Host Country Wages, Employment and Growth," Journal of Economic Perspectives, 9: 23-44.

[15] Hunt, Jennifer. 1992. "The Impact of the 1962 Repratriates from Algeria on the French Labor Market," Industrial and Labor Relations Review, 45: 556-572.

[16] LaLonde, Robert and Robert Topel. 1991. "Labor Market Adjustments to Increased Immigration," in John Abowd and Richard Freeman, eds., Immigration, Trade and Labor. Chicago: Chicago University Press.

[17] Migration News. 1999. Hurricane Mitch. UC Davis. (http://migration.ucdavis.edu/mn/more.php?id=1721_0_2_0).

[18] Morris, Saul, Oscar Neidcker-Gonzales, Calogero Carletto, Marcial Munguia and Quentin Wodon. 2000. "Hurricane Mitch and the Livelihood of the Rural Poor in Honduras," World Bank, Mimeo.

[19] Ottaviano, Gianmarco and Giovanni Peri. 2005. "Rethinking the Gains from Immigration: Theory and Evidence from the U.S.," NBER Working Paper No. 11672.

[20] Schoeni, Robert. 1996. "The Effect of Immigrants on the Employment and Wages of Native Workers: Evidence from the 1970s and 1980s," Mimeo, Rand.

[21] Tobar, Hector. 1999. "Painful Exodus Follows Hurricane's Havoc Immigration: Hordes Fleeing Mitch's Devastation Set Sights on Rio Grande," Los Angeles Time. (http://wwww.uwsa.com/pipermail/uwsa/1999q1/017734.html).

[22] Turk, Michele. 1999. After Hurricane Mitch, Hondurans' Hopes for Future Tied to U.S. (http://www.distaterrelief.org/Disasters/990128Mitch/index_txt.html).

[23] U.K. National Meteorological Office. 2004. Hurricane Mitch Fact Sheet. (http://wwww.metoffice.com/sec2/sec2cyclone/tcbulletins/mitch.html). 
[24] U.N. Economic Commission for Latin America and the Caribbean. 2001. Social Panorama of Latin America 2000-2001. Santiago, Chile: ECLAC. (http://www.eclac.cl/publicaciones/DesarrolloSocial/8/:CG2138PI/PSI2001_chap1.pdf).

[25] USAID. 2004. Hurricane Mitch: Program Overview. El Salvador: USAID.

[26] U.S. Department of Justice. 1998. News Release: Honduras, Nicaragua Designated for Temporary Protected Status Following Devastation from Hurricane Mitch. (http://www.rapidimmigration.com/www/news/news_295.html).

[27] U.S. National Weather Service. 1999. Preliminary Report: Hurricane Mitch. (http://www.nhc.noaa.gov/1998mitch.html).

[28] World Bank. 2001. Hurricane Mitch: The Gender Effects of Coping with Crisis. Washington, D.C.: World Bank. 
Table 1.A: Descriptive Statistics for Natives, by Education and Gender

\begin{tabular}{|c|c|c|c|c|c|c|}
\hline \multirow[b]{3}{*}{ Variable } & \multicolumn{6}{|c|}{ Natives } \\
\hline & \multicolumn{3}{|c|}{ Men } & \multicolumn{3}{|c|}{ Women } \\
\hline & Dropouts & HS & College & Dropouts & HS & College \\
\hline Hourly wage & $\begin{array}{c}12.86 \\
(36.83)\end{array}$ & $\begin{array}{c}15.44 \\
(34.87)\end{array}$ & $\begin{array}{c}21.25 \\
(65.52)\end{array}$ & $\begin{array}{c}9.04 \\
(25.11)\end{array}$ & $\begin{array}{c}10.82 \\
(27.94)\end{array}$ & $\begin{array}{c}15.30 \\
(48.75)\end{array}$ \\
\hline Employed & 55.58 & 78.87 & 85.44 & 36.93 & 59.58 & 72.66 \\
\hline Education & $\begin{array}{c}8.89 \\
(2.32)\end{array}$ & $\begin{array}{l}12 \\
(0)\end{array}$ & $\begin{array}{l}14.87 \\
(0.99)\end{array}$ & $\begin{array}{l}9.08 \\
(2.2)\end{array}$ & $\begin{array}{l}12 \\
(0)\end{array}$ & $\begin{array}{l}14.76 \\
(0.97)\end{array}$ \\
\hline Age & $\begin{array}{c}35.65 \\
(16.97)\end{array}$ & $\begin{array}{c}37.42 \\
(13.40)\end{array}$ & $\begin{array}{c}38.59 \\
(12.28)\end{array}$ & $\begin{array}{c}36.84 \\
(17.15)\end{array}$ & $\begin{array}{c}39.08 \\
(13.68)\end{array}$ & $\begin{array}{c}37.68 \\
(12.25)\end{array}$ \\
\hline Married & 45.88 & 59.78 & 64.18 & 45.10 & 64.02 & 60.16 \\
\hline Agriculture & 6.47 & 5.07 & 3.05 & 1.45 & 1.19 & 0.97 \\
\hline Construction & 11.47 & 13.07 & 6.94 & 0.61 & 1.27 & 1.19 \\
\hline Manufacturing & 18.30 & 23.99 & 17.43 & 11.70 & 13.09 & 7.09 \\
\hline Services & 49.98 & 52.93 & 70.06 & 63.80 & 72.11 & 83.93 \\
\hline White-collar & 15.79 & 24.92 & 59.62 & 23.65 & 44.16 & 66.18 \\
\hline Blue-collar & 77.49 & 72.11 & 38.81 & 67.84 & 50.27 & 30.13 \\
\hline Black & 16.30 & 11.10 & 6.85 & 17.30 & 11.25 & 9.40 \\
\hline Hispanic & 7.63 & 4.49 & 0.96 & 8.12 & 4.18 & 0.93 \\
\hline Asian & 0.55 & 0.56 & 3.24 & 0.53 & 0.50 & 3.38 \\
\hline $\mathrm{N}$ & $2,598,433$ & $3,822,868$ & $4,956,598$ & $2,494,766$ & $4,322,452$ & $5,029,246$ \\
\hline
\end{tabular}

Note: The table includes means and standard deviations for native men and women between the ages of 16 and 65. Hourly wages are deflated using the consumer price index. 
Table 1.B: Descriptive Statistics for Recent and Earlier Immigrants

\begin{tabular}{|c|c|c|c|c|}
\hline \multirow[b]{2}{*}{ Variable } & \multicolumn{2}{|c|}{ Latin American Immigrants } & \multicolumn{2}{|c|}{$\begin{array}{l}\text { Non-Latin American } \\
\text { Immigrants }\end{array}$} \\
\hline & Recent & Earlier & Recent & Earlier \\
\hline Hourly wage & $\begin{array}{c}10.31 \\
(27.90)\end{array}$ & $\begin{array}{c}14.28 \\
(52.59)\end{array}$ & $\begin{array}{c}15.52 \\
(39.91)\end{array}$ & $\begin{array}{c}17.01 \\
(45.78)\end{array}$ \\
\hline Employed & 58.05 & 63.36 & 55.03 & 68.31 \\
\hline Education & $\begin{array}{c}9.33 \\
(4.19)\end{array}$ & $\begin{array}{c}9.99 \\
(4.34)\end{array}$ & $\begin{array}{l}12.71 \\
(3.59)\end{array}$ & $\begin{array}{l}12.5 \\
(3.4)\end{array}$ \\
\hline Age & $\begin{array}{c}28.81 \\
(10.45)\end{array}$ & $\begin{array}{c}39.36 \\
(11.96)\end{array}$ & $\begin{array}{c}32.31 \\
(11.43)\end{array}$ & $\begin{array}{c}42.9 \\
(12.7)\end{array}$ \\
\hline Married & 47.67 & 64.78 & 42.28 & 68.34 \\
\hline Agriculture & 6.80 & 5.01 & 1.27 & 1.23 \\
\hline Construction & 9.35 & 7.07 & 2.97 & 4.14 \\
\hline Manufacturing & 16.64 & 17.58 & 14.10 & 16.27 \\
\hline Services & 49.30 & 57.25 & 62.97 & 66.51 \\
\hline White-collar & 22.32 & 31.90 & 40.96 & 45.36 \\
\hline Blue-collar & 67.09 & 58.99 & 49.94 & 48.20 \\
\hline Black & 8.07 & 10.83 & 5.9 & 2.93 \\
\hline Hispanic & 91.21 & 88.39 & - & - \\
\hline Asian & 0.82 & 0.78 & 47.37 & 17.38 \\
\hline $\mathrm{N}$ & 285,622 & 681,847 & 310,778 & 965,933 \\
\hline
\end{tabular}

Note: The table reports means and standard deviations for recent and earlier Latin American immigrants between the ages of 16 and 65. Recent and earlier Latin American immigrants include those who came less and more than 5 years ago, respectively. Hourly wages are deflated using the consumer price index. 
Table 2: OLS Estimates of the Effects of Latin American Immigration on Natives, and Earlier Latin American and Other Immigrants

\begin{tabular}{|c|c|c|c|c|c|c|}
\hline \multirow[b]{2}{*}{ Outcome } & \multicolumn{3}{|c|}{ Men } & \multicolumn{3}{|c|}{ Women } \\
\hline & Dropouts & HS & College & Dropouts & HS & College \\
\hline & \multicolumn{6}{|c|}{$\underline{\text { A. Natives }}$} \\
\hline Wages & $\begin{array}{c}0.025 \\
(0.015)\end{array}$ & $\begin{array}{c}0.039 \\
(0.009)\end{array}$ & $\begin{array}{c}0.042 \\
(0.006)\end{array}$ & $\begin{array}{c}0.027 \\
(0.009)\end{array}$ & $\begin{array}{c}0.042 \\
(0.007)\end{array}$ & $\begin{array}{c}0.041 \\
(0.005)\end{array}$ \\
\hline $\mathrm{N}$ & $1,499,488$ & $2,751,670$ & $3,503,638$ & $1,046,870$ & $2,588,808$ & $3,451,373$ \\
\hline Employment & $\begin{array}{c}-0.0005 \\
(0.009)\end{array}$ & $\begin{array}{c}-0.004 \\
(0.006)\end{array}$ & $\begin{array}{l}0.0002 \\
(0.004)\end{array}$ & $\begin{array}{l}0.0007 \\
(0.008)\end{array}$ & $\begin{array}{l}-0.010 \\
(0.004)\end{array}$ & $\begin{array}{c}-0.006 \\
(0.004)\end{array}$ \\
\hline \multirow[t]{2}{*}{$\mathrm{N}$} & $2,132,826$ & $3,466,460$ & $4,367,628$ & $1,642,230$ & $3,483,004$ & 4,333,307 \\
\hline & \multicolumn{6}{|c|}{ B. Earlier Latin American Immigrants } \\
\hline Wages & $\begin{array}{c}0.039 \\
(0.016)\end{array}$ & $\begin{array}{c}0.051 \\
(0.015)\end{array}$ & $\begin{array}{c}0.021 \\
(0.011)\end{array}$ & $\begin{array}{c}0.046 \\
(0.011)\end{array}$ & $\begin{array}{c}0.047 \\
(0.014)\end{array}$ & $\begin{array}{c}0.039 \\
(0.013)\end{array}$ \\
\hline $\mathrm{N}$ & 130,855 & 68,111 & 64,691 & 73,771 & 54,532 & 64,811 \\
\hline Employment & $\begin{array}{c}0.011 \\
(0.003)\end{array}$ & $\begin{array}{c}0.007 \\
(0.006)\end{array}$ & $\begin{array}{c}0.002 \\
(0.006)\end{array}$ & $\begin{array}{c}0.007 \\
(0.004)\end{array}$ & $\begin{array}{c}0.012 \\
(0.004)\end{array}$ & $\begin{array}{c}0.006 \\
(0.007)\end{array}$ \\
\hline \multirow[t]{2}{*}{$\mathrm{N}$} & 164,587 & 83,820 & 79,059 & 126,550 & 79,551 & 82,381 \\
\hline & \multicolumn{6}{|c|}{ C. Earlier Non-Latin American Immigrants } \\
\hline Wages & $\begin{array}{c}0.029 \\
(0.014)\end{array}$ & $\begin{array}{c}0.035 \\
(0.018)\end{array}$ & $\begin{array}{c}0.041 \\
(0.008)\end{array}$ & $\begin{array}{c}0.024 \\
(0.019)\end{array}$ & $\begin{array}{c}0.047 \\
(0.008)\end{array}$ & $\begin{array}{c}0.043 \\
(0.007)\end{array}$ \\
\hline $\mathrm{N}$ & 58,794 & 75,951 & 169,206 & 50,944 & 86,866 & 162,953 \\
\hline Employment & $\begin{array}{c}-0.003 \\
(0.0068)\end{array}$ & $\begin{array}{c}0.016 \\
(0.0038)\end{array}$ & $\begin{array}{c}0.016 \\
(0.0028)\end{array}$ & $\begin{array}{c}0.028 \\
(0.006)\end{array}$ & $\begin{array}{c}0.011 \\
(0.004)\end{array}$ & $\begin{array}{c}0.009 \\
(0.003)\end{array}$ \\
\hline $\mathrm{N}$ & 86,357 & 102,254 & 218,346 & 83,444 & 126,594 & 216,664 \\
\hline
\end{tabular}

Notes: The table reports OLS estimates of Latin American state shares on the log of hourly wages and an employment indicator. Standard errors are clustered by state and reported in parenthesis. All regressions control for years of education; potential experience and its square; a marriage dummy; black, Asian, and Hispanic dummies; and industry, occupation, state and year effects. 
Table 3: First Stage

\begin{tabular}{|c|c|c|c|c|c|c|c|}
\hline & $\begin{array}{l}\text { Share of } \\
\text { Latin } \\
\text { American } \\
\text { Imm. } \\
\end{array}$ & $\begin{array}{l}\text { Share of } \\
\text { African } \\
\text { Imm. }\end{array}$ & $\begin{array}{l}\text { Share of } \\
\text { East Asian } \\
\text { Imm. }\end{array}$ & $\begin{array}{c}\text { Share of } \\
\text { South Asian } \\
\text { Imm. } \\
\end{array}$ & $\begin{array}{c}\text { Share of } \\
\text { European } \\
\text { Imm. }\end{array}$ & $\begin{array}{c}\text { Share of } \\
\text { Australian } \\
\text { Imm. }\end{array}$ & $\begin{array}{c}\text { Share of } \\
\text { Middle } \\
\text { Eastern } \\
\text { Imm. }\end{array}$ \\
\hline & \multicolumn{7}{|c|}{$\underline{\text { A. Without Trends }}$} \\
\hline $\begin{array}{l}\text { Post-Mitch } \times \\
\text { Distance }\end{array}$ & $\begin{array}{l}-0.0016 \\
(0.0007)\end{array}$ & $\begin{array}{l}-0.0001 \\
(0.0001)\end{array}$ & $\begin{array}{l}-0.0004 \\
(0.0006)\end{array}$ & $\begin{array}{c}-0.00006 \\
(0.00006)\end{array}$ & $\begin{array}{c}0.0001 \\
(0.0001)\end{array}$ & $\begin{array}{c}0.0001 \\
(0.0001)\end{array}$ & $\begin{array}{l}-0.00004 \\
(0.00004)\end{array}$ \\
\hline \multirow[t]{2}{*}{$\mathrm{R}^{2}$} & 0.81 & 0.67 & 0.91 & 0.73 & 0.85 & 0.89 & 0.75 \\
\hline & \multicolumn{7}{|c|}{ B. With Trends } \\
\hline $\begin{array}{l}\text { Post-Mitch } \times \\
\text { Distance }\end{array}$ & $\begin{array}{l}-0.0019 \\
(0.0007)\end{array}$ & $\begin{array}{l}-0.00001 \\
(0.00011)\end{array}$ & $\begin{array}{l}-0.0009 \\
(0.0006)\end{array}$ & $\begin{array}{l}-0.00016 \\
(0.00009)\end{array}$ & $\begin{array}{c}0.0004 \\
(0.0002)\end{array}$ & $\begin{array}{c}0.0001 \\
(0.0001)\end{array}$ & $\begin{array}{l}-0.00004 \\
(0.00005)\end{array}$ \\
\hline Trend & $\begin{array}{l}-0.00003 \\
(0.00004)\end{array}$ & $\begin{array}{c}0.0001 \\
(0.0)\end{array}$ & $\begin{array}{l}-0.00005 \\
(0.00001)\end{array}$ & $\begin{array}{c}0.0 \\
(0.0)\end{array}$ & $\begin{array}{c}0.00003 \\
(0.0)\end{array}$ & $\begin{array}{c}0.0 \\
(0.0)\end{array}$ & $\begin{array}{c}0.0 \\
(0.0)\end{array}$ \\
\hline $\mathrm{R}^{2}$ & 0.81 & 0.67 & 0.91 & 0.72 & 0.86 & 0.89 & 0.76 \\
\hline
\end{tabular}

Notes: Standard errors are clustered by state and reported in parentheses. All regressions include state and year effects. The Distance variable measures the crow miles from Tegucigalpa to the Southern-most residential area in each state. 
Table 4: IV Estimates of the Effects of Latin American Immigration on Natives

\begin{tabular}{|c|c|c|c|c|c|c|}
\hline \multirow{2}{*}{$\begin{array}{c}\text { State- } \\
\text { Type } \\
\text { Trends } \\
\end{array}$} & \multicolumn{3}{|c|}{ Men } & \multicolumn{3}{|c|}{ Women } \\
\hline & Dropouts & HS & College & Dropouts & HS & College \\
\hline & \multicolumn{6}{|c|}{ A. Hourly Wages } \\
\hline No & $\begin{array}{c}0.141 \\
(0.099)\end{array}$ & $\begin{array}{c}0.066 \\
(0.035)\end{array}$ & $\begin{array}{c}0.066 \\
(0.025)\end{array}$ & $\begin{array}{c}0.043 \\
(0.035)\end{array}$ & $\begin{array}{l}-0.007 \\
(0.025)\end{array}$ & $\begin{array}{c}-0.012 \\
(0.018)\end{array}$ \\
\hline Yes & $\begin{array}{c}0.061 \\
(0.044)\end{array}$ & $\begin{array}{c}0.081 \\
(0.034)\end{array}$ & $\begin{array}{c}0.063 \\
(0.022)\end{array}$ & $\begin{array}{c}0.011 \\
(0.029)\end{array}$ & $\begin{array}{c}0.044 \\
(0.021)\end{array}$ & $\begin{array}{c}0.029 \\
(0.016)\end{array}$ \\
\hline Trend & $\begin{array}{c}0.001 \\
(0.001)\end{array}$ & $\begin{array}{c}-0.0003 \\
(0.0008)\end{array}$ & $\begin{array}{c}0.0001 \\
(0.0005)\end{array}$ & $\begin{array}{c}0.0007 \\
(0.0009)\end{array}$ & $\begin{array}{c}-0.001 \\
(0.0006)\end{array}$ & $\begin{array}{c}-0.001 \\
(0.0005)\end{array}$ \\
\hline \multirow[t]{2}{*}{$\mathrm{N}$} & $1,499,488$ & $2,751,670$ & $3,503,638$ & $1,046,870$ & $2,588,808$ & $3,451,373$ \\
\hline & \multicolumn{6}{|c|}{ B. Employment } \\
\hline No & $\begin{array}{l}-0.070 \\
(0.049)\end{array}$ & $\begin{array}{l}-0.026 \\
(0.032)\end{array}$ & $\begin{array}{c}-0.002 \\
(0.013)\end{array}$ & $\begin{array}{l}-0.125 \\
(0.086)\end{array}$ & $\begin{array}{l}-0.058 \\
(0.037)\end{array}$ & $\begin{array}{c}-0.023 \\
(0.018)\end{array}$ \\
\hline Yes & $\begin{array}{l}-0.058 \\
(0.044)\end{array}$ & $\begin{array}{c}-0.021 \\
(0.024)\end{array}$ & $\begin{array}{l}-0.004 \\
(0.010)\end{array}$ & $\begin{array}{l}-0.062 \\
(0.044)\end{array}$ & $\begin{array}{l}-0.029 \\
(0.021)\end{array}$ & $\begin{array}{c}-0.013 \\
(0.011)\end{array}$ \\
\hline Trend & $\begin{array}{c}-0.0002 \\
(0.0006)\end{array}$ & $\begin{array}{c}-0.0001 \\
(0.0003)\end{array}$ & $\begin{array}{l}0.00006 \\
(0.0002)\end{array}$ & $\begin{array}{c}-0.0012 \\
(0.0007)\end{array}$ & $\begin{array}{l}-0.0007 \\
(0.0003)\end{array}$ & $\begin{array}{l}-0.0003 \\
(0.0003)\end{array}$ \\
\hline $\mathrm{N}$ & 2,132,826 & $3,466,460$ & $4,367,628$ & $1,642,230$ & $3,483,004$ & $4,333,307$ \\
\hline
\end{tabular}

Notes: The table reports IV estimates of Latin American state shares on log hourly wages and an employment indicator for natives. The Latin American share is instrumented with the interaction between a post-Mitch dummy and distance from Tegucigalpa to the Southern-most residential area in each state. Standard errors are clustered by state and reported in parenthesis. Regressions control for years of education; potential experience and its square; a marriage dummy; black, Asian, and Hispanic dummies; and industry, occupation, state and year effects. 
Table 5: IV Estimates of the Effects of Recent Latin American Immigration on Earlier Latin American Immigrants

\begin{tabular}{|c|c|c|c|c|c|c|}
\hline \multirow{2}{*}{$\begin{array}{l}\text { State- } \\
\text { Type } \\
\text { Trends }\end{array}$} & \multicolumn{3}{|c|}{ Men } & \multicolumn{3}{|c|}{ Women } \\
\hline & Dropouts & HS & College & Dropouts & HS & College \\
\hline & \multicolumn{6}{|c|}{$\underline{\text { A. Hourly Wages }}$} \\
\hline No & $\begin{array}{c}0.074 \\
(0.028)\end{array}$ & $\begin{array}{c}0.059 \\
(0.017)\end{array}$ & $\begin{array}{c}0.021 \\
(0.016)\end{array}$ & $\begin{array}{c}0.079 \\
(0.011)\end{array}$ & $\begin{array}{c}0.054 \\
(0.014)\end{array}$ & $\begin{array}{c}0.028 \\
(0.019)\end{array}$ \\
\hline Yes & $\begin{array}{c}0.032 \\
(0.024)\end{array}$ & $\begin{array}{c}0.049 \\
(0.029)\end{array}$ & $\begin{array}{c}0.049 \\
(0.024)\end{array}$ & $\begin{array}{c}0.014 \\
(0.020)\end{array}$ & $\begin{array}{c}0.036 \\
(0.021)\end{array}$ & $\begin{array}{c}-0.001 \\
(0.038)\end{array}$ \\
\hline Trend & $\begin{array}{c}0.00354 \\
(0.0018)\end{array}$ & $\begin{array}{c}0.0008 \\
(0.0022)\end{array}$ & $\begin{array}{c}-0.0024 \\
(0.0017)\end{array}$ & $\begin{array}{c}0.0057 \\
(0.0019)\end{array}$ & $\begin{array}{c}0.0016 \\
(0.0013)\end{array}$ & $\begin{array}{c}0.0025 \\
(0.0017)\end{array}$ \\
\hline \multirow[t]{2}{*}{$\mathrm{N}$} & 130,855 & 68,111 & 64,691 & 73,771 & 54,532 & 64,811 \\
\hline & \multicolumn{6}{|c|}{ B. Employment } \\
\hline No & $\begin{array}{c}0.007 \\
(0.006)\end{array}$ & $\begin{array}{c}0.004 \\
(0.007)\end{array}$ & $\begin{array}{c}-0.003 \\
(0.008)\end{array}$ & $\begin{array}{c}0.005 \\
(0.009)\end{array}$ & $\begin{array}{c}0.009 \\
(0.008)\end{array}$ & $\begin{array}{c}0.001 \\
(0.012)\end{array}$ \\
\hline Yes & $\begin{array}{c}0.017 \\
(0.007)\end{array}$ & $\begin{array}{c}0.001 \\
(0.013)\end{array}$ & $\begin{array}{c}-0.009 \\
(0.014)\end{array}$ & $\begin{array}{c}-0.006 \\
(0.012)\end{array}$ & $\begin{array}{r}-0.0007 \\
(0.012)\end{array}$ & $\begin{array}{c}-0.025 \\
(0.023)\end{array}$ \\
\hline Trend & $\begin{array}{l}-0.0009 \\
(0.0005)\end{array}$ & $\begin{array}{c}0.0002 \\
(0.0008)\end{array}$ & $\begin{array}{c}0.0005 \\
(0.0006)\end{array}$ & $\begin{array}{c}0.0009 \\
(0.0012)\end{array}$ & $\begin{array}{c}0.0008 \\
(0.0006)\end{array}$ & $\begin{array}{c}0.002 \\
(0.0009)\end{array}$ \\
\hline $\mathrm{N}$ & 164,587 & 83,820 & 79,059 & 126,550 & 79,551 & 82,381 \\
\hline
\end{tabular}

Notes: The table reports IV estimates of recent Latin American state shares on log hourly wages and an employment indicator for earlier Latin American immigrants. The Latin American share is instrumented with the interaction between a post-Mitch dummy and distance from Tegucigalpa to the Southern-most residential area in each state. Standard errors are clustered by state and reported in parenthesis. Regressions control for years of education; potential experience and its square; a marriage dummy; black, Asian, and Hispanic dummies; and industry, occupation, state and year effects. 
Table 6: IV Estimates of the Effects of Latin American Immigration on Earlier Non-Latin American Immigrants

\begin{tabular}{|c|c|c|c|c|c|c|}
\hline \multirow{2}{*}{$\begin{array}{l}\text { State- } \\
\text { Type } \\
\text { Trends }\end{array}$} & \multicolumn{3}{|c|}{ Men } & \multicolumn{3}{|c|}{ Women } \\
\hline & Dropouts & HS & College & Dropouts & HS & College \\
\hline & \multicolumn{6}{|c|}{ A. Hourly Wages } \\
\hline No & $\begin{array}{c}0.085 \\
(0.073)\end{array}$ & $\begin{array}{c}0.096 \\
(0.042)\end{array}$ & $\begin{array}{c}0.054 \\
(0.023)\end{array}$ & $\begin{array}{c}0.139 \\
(0.054)\end{array}$ & $\begin{array}{c}0.035 \\
(0.041)\end{array}$ & $\begin{array}{c}0.029 \\
(0.017)\end{array}$ \\
\hline Yes & $\begin{array}{c}0.079 \\
(0.064)\end{array}$ & $\begin{array}{c}0.061 \\
(0.044)\end{array}$ & $\begin{array}{c}0.041 \\
(0.024)\end{array}$ & $\begin{array}{c}0.047 \\
(0.056)\end{array}$ & $\begin{array}{c}0.033 \\
(0.045)\end{array}$ & $\begin{array}{c}0.015 \\
(0.024)\end{array}$ \\
\hline Trend & $\begin{array}{c}0.0001 \\
(0.0019)\end{array}$ & $\begin{array}{c}0.0014 \\
(0.0010)\end{array}$ & $\begin{array}{c}0.0007 \\
(0.0007)\end{array}$ & $\begin{array}{c}0.0033 \\
(0.0026)\end{array}$ & $\begin{array}{c}0.0000 \\
(0.0008)\end{array}$ & $\begin{array}{c}0.0009 \\
(0.0014)\end{array}$ \\
\hline \multirow[t]{2}{*}{$\mathrm{N}$} & 58,794 & 75,911 & 169,206 & 50,944 & 86,866 & 162,953 \\
\hline & \multicolumn{6}{|c|}{ B. Employment } \\
\hline No & $\begin{array}{c}0.061 \\
(0.025)\end{array}$ & $\begin{array}{c}0.080 \\
(0.034)\end{array}$ & $\begin{array}{c}0.041 \\
(0.014)\end{array}$ & $\begin{array}{c}0.079 \\
(0.040)\end{array}$ & $\begin{array}{l}0.0041 \\
(0.022)\end{array}$ & $\begin{array}{c}0.031 \\
(0.012)\end{array}$ \\
\hline Yes & $\begin{array}{l}0.0023 \\
(0.025)\end{array}$ & $\begin{array}{c}0.041 \\
(0.035)\end{array}$ & $\begin{array}{c}0.016 \\
(0.016)\end{array}$ & $\begin{array}{c}-0.019 \\
(0.039)\end{array}$ & $\begin{array}{c}-0.008 \\
(0.027)\end{array}$ & $\begin{array}{c}0.028 \\
(0.018)\end{array}$ \\
\hline Trend & $\begin{array}{c}0.0018 \\
(0.0009)\end{array}$ & $\begin{array}{c}0.0016 \\
(0.0005)\end{array}$ & $\begin{array}{c}0.0014 \\
(0.0005)\end{array}$ & $\begin{array}{c}0.0031 \\
(0.0009)\end{array}$ & $\begin{array}{c}0.021 \\
(0.0005)\end{array}$ & $\begin{array}{c}0.0000 \\
(0.0007)\end{array}$ \\
\hline $\mathrm{N}$ & 86,357 & 102,254 & 218,346 & 83,444 & 126,594 & 216,664 \\
\hline
\end{tabular}

Notes: The table reports IV estimates of Latin American state shares of on log hourly wages and an employment indicator for earlier non-Latin American immigrants. The Latin American share is instrumented with the interaction between a post-Mitch dummy and distance from Tegucigalpa to the Southern-most residential area in each state. Standard errors are clustered by state and are reported in parenthesis. Regressions control for years of education; potential experience and its square; a marriage dummy; black, Asian, and Hispanic dummies; and industry, occupation, state and year effects. 
Table 7: Effects of Recent Latin American Immigration on the Native and Earlier Immigrant Populations

\begin{tabular}{|c|c|c|c|c|c|c|c|c|}
\hline & $\begin{array}{l}\text { Share of } \\
\text { Natives }\end{array}$ & $\begin{array}{c}\text { Share } \\
\text { Earlier } \\
\text { Latin Am. } \\
\text { Imm. } \\
\end{array}$ & $\begin{array}{c}\text { Share } \\
\text { Earlier } \\
\text { African } \\
\text { Imm. } \\
\end{array}$ & $\begin{array}{c}\text { Share } \\
\text { Earlier } \\
\text { East Asian } \\
\text { Imm. } \\
\end{array}$ & $\begin{array}{c}\text { Share } \\
\text { Ealier } \\
\text { South As. } \\
\text { Imm. } \\
\end{array}$ & $\begin{array}{l}\text { Share } \\
\text { Earlier } \\
\text { Europ. } \\
\text { Imm. }\end{array}$ & $\begin{array}{l}\text { Share } \\
\text { Earlier } \\
\text { Austr. } \\
\text { Imm. }\end{array}$ & $\begin{array}{c}\text { Share } \\
\text { Earlier } \\
\text { Middle } \\
\text { East. Imm. }\end{array}$ \\
\hline & \multicolumn{8}{|c|}{ A. Without trends } \\
\hline $\begin{array}{l}\text { Post-Mitch } \\
\times \text { Distance }\end{array}$ & $\begin{array}{l}-0.002 \\
(0.004)\end{array}$ & $\begin{array}{l}-0.002 \\
(0.002)\end{array}$ & $\begin{array}{c}-0.0001 \\
(0.0000)\end{array}$ & $\begin{array}{c}0.0088 \\
(0.0030)\end{array}$ & $\begin{array}{c}-0.0000 \\
(0.0001)\end{array}$ & $\begin{array}{c}-0.0007 \\
(0.0008)\end{array}$ & $\begin{array}{c}0.0008 \\
(0.0003)\end{array}$ & $\begin{array}{c}-0.00004 \\
(0.00004)\end{array}$ \\
\hline \multirow[t]{2}{*}{$\mathrm{R}^{2}$} & 0.89 & 0.69 & 0.60 & 0.91 & 0.61 & 0.91 & 0.82 & 0.76 \\
\hline & \multicolumn{8}{|c|}{ B. With Trends } \\
\hline $\begin{array}{l}\text { Post-Mitch } \\
\times \text { Distance }\end{array}$ & $\begin{array}{l}-0.004 \\
(0.005)\end{array}$ & $\begin{array}{l}-0.003 \\
(0.002)\end{array}$ & $\begin{array}{c}-0.0000 \\
(0.0000)\end{array}$ & $\begin{array}{c}0.0095 \\
(0.0034)\end{array}$ & $\begin{array}{c}-0.0001 \\
(0.0001)\end{array}$ & $\begin{array}{c}0.0029 \\
(0.0007)\end{array}$ & $\begin{array}{c}0.0009 \\
(0.0003)\end{array}$ & $\begin{array}{c}-0.00004 \\
(0.00005)\end{array}$ \\
\hline Trend & $\begin{array}{c}-0.0002 \\
(-0.0003)\end{array}$ & $\begin{array}{l}-0.0001 \\
(0.0001)\end{array}$ & $\begin{array}{c}0.0000 \\
(0.0000)\end{array}$ & $\begin{array}{c}0.0000 \\
(0.0000)\end{array}$ & $\begin{array}{c}-0.0000 \\
(0.0000)\end{array}$ & $\begin{array}{c}0.0003 \\
(0.0000)\end{array}$ & $\begin{array}{c}0.0000 \\
(0.0000)\end{array}$ & $\begin{array}{c}0.0000 \\
(0.0000)\end{array}$ \\
\hline $\mathrm{R}^{2}$ & 0.89 & 0.69 & 0.60 & 0.90 & 0.61 & 0.94 & 0.83 & 0.76 \\
\hline
\end{tabular}

Notes: Standard errors are clustered by state and reported in parentheses. All regressions include state and year effects. The Distance variable measures the crow miles from Tegucigalpa to the Southern-most residential area in each state. 
Table 8: IV Estimates of the Effects of Recent Latin American, and Earlier Asian, European and Australian Immigration on Natives

\begin{tabular}{|c|c|c|c|c|c|c|}
\hline \multirow{2}{*}{$\begin{array}{c}\text { State- } \\
\text { Type } \\
\text { Trends }\end{array}$} & \multicolumn{3}{|c|}{ Men } & \multicolumn{3}{|c|}{ Women } \\
\hline & Dropouts & HS & College & Dropouts & HS & College \\
\hline & \multicolumn{6}{|c|}{ A. Hourly Wages } \\
\hline Latin & $\begin{array}{c}0.046 \\
(0.027)\end{array}$ & $\begin{array}{l}0.062 \\
(0.026)\end{array}$ & $\begin{array}{c}0.053 \\
(0.021)\end{array}$ & $\begin{array}{c}0.021 \\
(0.021)\end{array}$ & $\begin{array}{c}0.032 \\
(0.021)\end{array}$ & $\begin{array}{c}0.028 \\
(0.023)\end{array}$ \\
\hline Trend & $\begin{array}{c}-0.002 \\
(0.0016)\end{array}$ & $\begin{array}{l}-0.0011 \\
(0.0011)\end{array}$ & $\begin{array}{l}-0.0000 \\
(0.0005)\end{array}$ & $\begin{array}{l}-0.0022 \\
(0.0008)\end{array}$ & $\begin{array}{l}-0.0017 \\
(0.0008)\end{array}$ & $\begin{array}{c}-0.0011 \\
(0.0005)\end{array}$ \\
\hline East Asia & $\begin{array}{c}0.007 \\
(0.016)\end{array}$ & $\begin{array}{c}0.010 \\
(0.012)\end{array}$ & $\begin{array}{c}0.011 \\
(0.007)\end{array}$ & $\begin{array}{c}-0.003 \\
(0.008)\end{array}$ & $\begin{array}{l}-0.007 \\
(0.008)\end{array}$ & $\begin{array}{c}0.008 \\
(0.007)\end{array}$ \\
\hline Europe & $\begin{array}{c}0.028 \\
(0.033)\end{array}$ & $\begin{array}{l}-0.017 \\
(0.025)\end{array}$ & $\begin{array}{l}-0.018 \\
(0.017)\end{array}$ & $\begin{array}{c}0.028 \\
(0.015)\end{array}$ & $\begin{array}{c}-0.012 \\
(0.015)\end{array}$ & $\begin{array}{l}-0.009 \\
(0.013)\end{array}$ \\
\hline Australia & $\begin{array}{l}-1.185 \\
(0.970)\end{array}$ & $\begin{array}{l}-0.559 \\
(0.633)\end{array}$ & $\begin{array}{c}-0.374 \\
(0.327)\end{array}$ & $\begin{array}{c}-0.571 \\
(0.475)\end{array}$ & $\begin{array}{c}-0.027 \\
(0.351)\end{array}$ & $\begin{array}{l}-0.117 \\
(0.211)\end{array}$ \\
\hline \multirow[t]{2}{*}{$\mathrm{N}$} & $1,385,302$ & $2,656,858$ & $3,425,277$ & 992,691 & $2,537,552$ & $3,415,642$ \\
\hline & \multicolumn{6}{|c|}{ B. Employment } \\
\hline Latin & $\begin{array}{c}-0.047 \\
(0.019)\end{array}$ & $\begin{array}{l}-0.032 \\
(0.012)\end{array}$ & $\begin{array}{l}-0.014 \\
(0.007)\end{array}$ & $\begin{array}{c}-0.048 \\
(0.024)\end{array}$ & $\begin{array}{c}-0.033 \\
(0.015)\end{array}$ & $\begin{array}{l}-0.028 \\
(0.009)\end{array}$ \\
\hline Trend & $\begin{array}{c}-0.0010 \\
(0.0007)\end{array}$ & $\begin{array}{l}-0.0013 \\
(0.0005)\end{array}$ & $\begin{array}{l}-0.0008 \\
(0.0002)\end{array}$ & $\begin{array}{c}-0.0014 \\
(0.0008)\end{array}$ & $\begin{array}{c}-0.0014 \\
(0.0005)\end{array}$ & $\begin{array}{c}-0.0011 \\
(0.0002)\end{array}$ \\
\hline East Asia & $\begin{array}{l}-0.035 \\
(0.008)\end{array}$ & $\begin{array}{l}-0.037 \\
(0.004)\end{array}$ & $\begin{array}{l}-0.018 \\
(0.002)\end{array}$ & $\begin{array}{c}-0.031 \\
(0.008)\end{array}$ & $\begin{array}{l}-0.028 \\
(0.004)\end{array}$ & $\begin{array}{l}-0.023 \\
(0.003)\end{array}$ \\
\hline Europe & $\begin{array}{c}0.001 \\
(0.014)\end{array}$ & $\begin{array}{c}0.005 \\
(0.009)\end{array}$ & $\begin{array}{c}0.007 \\
(0.004)\end{array}$ & $\begin{array}{c}0.003 \\
(0.015)\end{array}$ & $\begin{array}{c}0.012 \\
(0.009)\end{array}$ & $\begin{array}{c}0.010 \\
(0.004)\end{array}$ \\
\hline Australia & $\begin{array}{c}0.743 \\
(0.462)\end{array}$ & $\begin{array}{c}0.422 \\
(0.217)\end{array}$ & $\begin{array}{c}0.158 \\
(0.089)\end{array}$ & $\begin{array}{c}0.681 \\
(0.461)\end{array}$ & $\begin{array}{c}0.419 \\
(0.221)\end{array}$ & $\begin{array}{c}0.214 \\
(0.079)\end{array}$ \\
\hline $\mathrm{N}$ & $1,960,745$ & $3,342,580$ & $4,260,613$ & $1,530,673$ & 3,383,990 & $4,269,979$ \\
\hline
\end{tabular}

Notes: The table reports IV estimates of Latin American shares and earlier East Asian, European and Australian immigrant shares on log hourly wages and an employment indicator of natives. The Latin American share is instrumented with the interaction between a post-Mitch dummy and distance from Tegucigalpa to the Southern-most residential area in each state. The East Asian, European and Australian shares are instrumented with the lag shares for each of these groups. Standard errors are clustered by state and are reported in parenthesis. Regressions control for years of education; potential experience and its square; a marriage dummy; black, Asian, and Hispanic dummies; and industry, occupation, state and year effects. 
Table 9: IV Estimates of the Effects of Recent Latin American and Earlier East Asian, European and Australian Immigration on Earlier Latin American Immigrants

\begin{tabular}{|c|c|c|c|c|c|c|}
\hline \multirow{2}{*}{$\begin{array}{c}\text { State-Type } \\
\text { Trends } \\
\end{array}$} & \multicolumn{3}{|c|}{ Men } & \multicolumn{3}{|c|}{ Women } \\
\hline & Dropouts & HS & College & Dropouts & HS & College \\
\hline & \multicolumn{6}{|c|}{$\underline{\text { A. Hourly Wages }}$} \\
\hline Latin & $\begin{array}{c}0.058 \\
(0.039)\end{array}$ & $\begin{array}{c}0.033 \\
(0.055)\end{array}$ & $\begin{array}{c}0.012 \\
(0.036)\end{array}$ & $\begin{array}{c}0.032 \\
(0.029)\end{array}$ & $\begin{array}{c}0.055 \\
(0.049)\end{array}$ & $\begin{array}{c}-0.005 \\
(0.063)\end{array}$ \\
\hline Trend & $\begin{array}{c}0.0009 \\
(0.0027)\end{array}$ & $\begin{array}{c}0.0016 \\
(0.0028)\end{array}$ & $\begin{array}{c}-0.0002 \\
(0.0014)\end{array}$ & $\begin{array}{c}0.0010 \\
(0.0027)\end{array}$ & $\begin{array}{c}0.0002 \\
(0.0019)\end{array}$ & $\begin{array}{c}0.0000 \\
(0.0015)\end{array}$ \\
\hline East Asia & $\begin{array}{c}0.024 \\
(0.052)\end{array}$ & $\begin{array}{c}-0.014 \\
(0.051)\end{array}$ & $\begin{array}{c}0.007 \\
(0.024)\end{array}$ & $\begin{array}{c}-0.006 \\
(0.031)\end{array}$ & $\begin{array}{c}-0.023 \\
(0.031)\end{array}$ & $\begin{array}{c}-0.067 \\
(0.044)\end{array}$ \\
\hline Europe & $\begin{array}{c}0.029 \\
(0.065)\end{array}$ & $\begin{array}{c}-0.057 \\
(0.049)\end{array}$ & $\begin{array}{c}-0.039 \\
(0.027)\end{array}$ & $\begin{array}{c}0.032 \\
(0.036)\end{array}$ & $\begin{array}{c}-0.001 \\
(0.035)\end{array}$ & $\begin{array}{c}0.011 \\
(0.039)\end{array}$ \\
\hline Australia & $\begin{array}{c}-0.889 \\
(2.125)\end{array}$ & $\begin{array}{l}0.508 \\
(1.05)\end{array}$ & $\begin{array}{c}-0.754 \\
(0.692)\end{array}$ & $\begin{array}{c}-0.428 \\
(1.308)\end{array}$ & $\begin{array}{c}1.265 \\
(0.756)\end{array}$ & $\begin{array}{c}2.268 \\
(1.027)\end{array}$ \\
\hline \multirow[t]{2}{*}{$\mathrm{N}$} & 129,743 & 67,830 & 64,400 & 73,298 & 54,331 & 64,700 \\
\hline & \multicolumn{6}{|c|}{ B. Employment } \\
\hline Latin & $\begin{array}{c}0.009 \\
(0.012)\end{array}$ & $\begin{array}{l}-0.012 \\
(0.019)\end{array}$ & $\begin{array}{c}-0.014 \\
(0.012)\end{array}$ & $\begin{array}{c}0.002 \\
(0.015)\end{array}$ & $\begin{array}{c}-0.004 \\
(0.009)\end{array}$ & $\begin{array}{l}-0.017 \\
(0.012)\end{array}$ \\
\hline Trend & $\begin{array}{l}-0.002 \\
(0.001)\end{array}$ & $\begin{array}{l}-0.001 \\
(0.000)\end{array}$ & $\begin{array}{c}-0.002 \\
(0.000)\end{array}$ & $\begin{array}{c}-0.000 \\
(0.000)\end{array}$ & $\begin{array}{c}-0.002 \\
(0.000)\end{array}$ & $\begin{array}{c}-0.003 \\
(0.000)\end{array}$ \\
\hline East Asia & $\begin{array}{c}0.001 \\
(0.021)\end{array}$ & $\begin{array}{l}-0.026 \\
(0.020)\end{array}$ & $\begin{array}{c}-0.031 \\
(0.012)\end{array}$ & $\begin{array}{c}0.007 \\
(0.026)\end{array}$ & $\begin{array}{l}-0.037 \\
(0.008)\end{array}$ & $\begin{array}{c}-0.029 \\
(0.011)\end{array}$ \\
\hline Europe & $\begin{array}{c}0.067 \\
(0.029)\end{array}$ & $\begin{array}{c}0.028 \\
(0.019)\end{array}$ & $\begin{array}{l}0.039 \\
(0.011)\end{array}$ & $\begin{array}{c}0.068 \\
(0.026)\end{array}$ & $\begin{array}{c}0.019 \\
(0.010)\end{array}$ & $\begin{array}{l}0.047 \\
(0.011)\end{array}$ \\
\hline Australia & $\begin{array}{l}-0.566 \\
(1.34)\end{array}$ & $\begin{array}{l}0.212 \\
(0.84)\end{array}$ & $\begin{array}{c}0.395 \\
(0.533)\end{array}$ & $\begin{array}{r}-0.616 \\
(1.41)\end{array}$ & $\begin{array}{l}0.825 \\
(0.198)\end{array}$ & $\begin{array}{c}-0.006 \\
(0.462)\end{array}$ \\
\hline $\mathrm{N}$ & 163,086 & 83,449 & 78,663 & 125,574 & 79,216 & 82,171 \\
\hline
\end{tabular}

Notes: The table reports IV estimates of Latin American shares and earlier East Asian, European and Australian immigrant shares on log hourly wages and an employment indicator of earlier Latin American immigrants. The Latin American share is instrumented with the interaction between a post-Mitch dummy and distance from Tegucigalpa to the Southern-most residential area in each state. The East Asian, European and Australian shares are instrumented with the lag shares for each of these groups. Standard errors are clustered by state and are reported in parenthesis. Regressions control for years of education; potential experience and its square; a marriage dummy; black, Asian, and Hispanic dummies; and industry, occupation, state and year effects. 
Table A.1: Distances from the Central American Capital Cities to the Southern-Most Cities in U.S. States

\begin{tabular}{|c|c|c|c|c|c|c|}
\hline State & $\begin{array}{l}\text { Southern-Most } \\
\text { City }\end{array}$ & Tegucigalpa & Managua & $\begin{array}{l}\text { Guatemala } \\
\text { city }\end{array}$ & $\begin{array}{c}\text { San } \\
\text { Salvador }\end{array}$ & $\begin{array}{c}\text { Average } \\
\text { Central } \\
\text { American } \\
\text { Capitals }\end{array}$ \\
\hline Alabama & Grand Bay & 1131 & 1266 & 1105 & 1157 & 1164.75 \\
\hline Alaska & Juneau & 3891 & 4037 & 3759 & 3856 & 3885.75 \\
\hline Arizona & Douglas & 1848 & 1985 & 1666 & 1776 & 1818.75 \\
\hline Arkansas & Texarkana & 1401 & 1544 & 1317 & 1394 & 1414 \\
\hline California & El Centro & 2201 & 2335 & 2009 & 2121 & 2166.5 \\
\hline Colorado & Trinidad & 1912 & 2056 & 1767 & 1867 & 1900.5 \\
\hline Connecticut & Bridgeport & 2050 & 2021 & 1977 & 1992 & 2010 \\
\hline Delaware & Laurel & 1830 & 1932 & 1886 & 1902 & 1887.5 \\
\hline Washington & D.C. & 1820 & 1927 & 1866 & 1887 & 1875 \\
\hline Florida & Key West & 804 & 902 & 892 & 888 & 871.5 \\
\hline Georgia & Bainbridge & 1171 & 1294 & 1185 & 1219 & 1217.25 \\
\hline Hawaii & Honolulu & 4644 & 4745 & 4421 & 4530 & 4585 \\
\hline Idaho & Preston & 2429 & 2574 & 2286 & 2385 & 2418.5 \\
\hline Illinois & Mound City & 1589 & 1723 & 1556 & 1612 & 1620 \\
\hline Indiana & Evansville & 1647 & 1779 & 1622 & 1675 & 1680.75 \\
\hline Iowa & Keokuk & 1832 & 1970 & 1779 & 1844 & 1856.25 \\
\hline Kansas & Oswego & 1663 & 1807 & 1566 & 1649 & 1671.25 \\
\hline Kentucky & Hickman & 1553 & 1676 & 1560 & 1598 & 1596.75 \\
\hline Louisiana & Cameron & 1150 & 1294 & 1062 & 1139 & 1161.25 \\
\hline Maine & Kittery & 2226 & 2324 & 2288 & 2301 & 2284.75 \\
\hline Maryland & Crisfield & 1788 & 1890 & 1847 & 1861 & 1846.5 \\
\hline Massachusetts & Barrington & 2107 & 2202 & 2174 & 2184 & 2166.75 \\
\hline Michigan & Cassopolis & 1919 & 2044 & 1915 & 1959 & 1959.25 \\
\hline Minnesota & Fairmont & 2082 & 2222 & 2015 & 2087 & 2101.5 \\
\hline Mississippi & Biloxi & 1130 & 1267 & 1094 & 1150 & 1160.25 \\
\hline Missouri & Caruthersville & 1530 & 1666 & 1488 & 1548 & 1558 \\
\hline Montana & Red Lodge & 2502 & 2648 & 2376 & 2470 & 2499 \\
\hline Nebraska & Falls City & 1861 & 2005 & 1772 & 1852 & 1872.5 \\
\hline Nevada & Laughlin & 2240 & 2378 & 2061 & 2170 & 2212.25 \\
\hline N. Hampshire & Keene & 2179 & 2277 & 2238 & 2252 & 2236.5 \\
\hline New Jersey & Cape may & 1870 & 1971 & 1929 & 1943 & 1928.25 \\
\hline New Mexico & Hobbs & 1631 & 1775 & 1481 & 1582 & 1617.25 \\
\hline New York & N.Y. City & 2000 & 2101 & 2056 & 2072 & 2057.25 \\
\hline North Carolina & Murphy & 1461 & 1563 & 1522 & 1534 & 1520 \\
\hline North Dakota & Forman & 2289 & 2431 & 2206 & 2284 & 2302.5 \\
\hline Ohio & Ironton & 1707 & 1833 & 1703 & 1747 & 1747.5 \\
\hline Oklahoma & Idabel & 1446 & 1591 & 1326 & 1417 & 1445 \\
\hline Oregon & Lakeview & 2768 & 2910 & 2602 & 2708 & 2747 \\
\hline Pennsylvania & Waynesburg & 1829 & 1953 & 1902 & 1920 & 1901 \\
\hline Rhode Island & Westerly & 2096 & 2193 & 2161 & 2172 & 2155.5 \\
\hline South Carolina & Hilton head & 1313 & 1422 & 1360 & 1379 & 1368.5 \\
\hline South Dakota & Vermillion & 2061 & 2203 & 1979 & 2056 & 2074.75 \\
\hline Tennessee & Chattanooga & 1451 & 1577 & 1448 & 1490 & 1491.5 \\
\hline Texas & Brownsville & 1053 & 1196 & 901 & 1001 & 1037.75 \\
\hline Utah & Kanab & 2220 & 2362 & 2054 & 2160 & 2199 \\
\hline Vermont & Pennington & 2153 & 2254 & 2207 & 2224 & 2209.5 \\
\hline Virginia & Jonesville & 1578 & 1678 & 1639 & 1651 & 1636.5 \\
\hline Washington & Walla Walla & 2851 & 2995 & 2697 & 2800 & 2835.75 \\
\hline West Virginia & Bluefield & 1639 & 1755 & 1663 & 1694 & 1687.75 \\
\hline Wisconsin & Kenosha & 1964 & 2097 & 1935 & 1991 & 1996.75 \\
\hline Wyoming & Cheyenne & 2144 & 2290 & 2020 & 2113 & 2141.75 \\
\hline
\end{tabular}

Notes: The table reports straight-line miles from each Central American Capital city to the Southern-most city in each U.S. state. 
Central American Countries Affected by Hurricane Mitch and U.S. Southern States

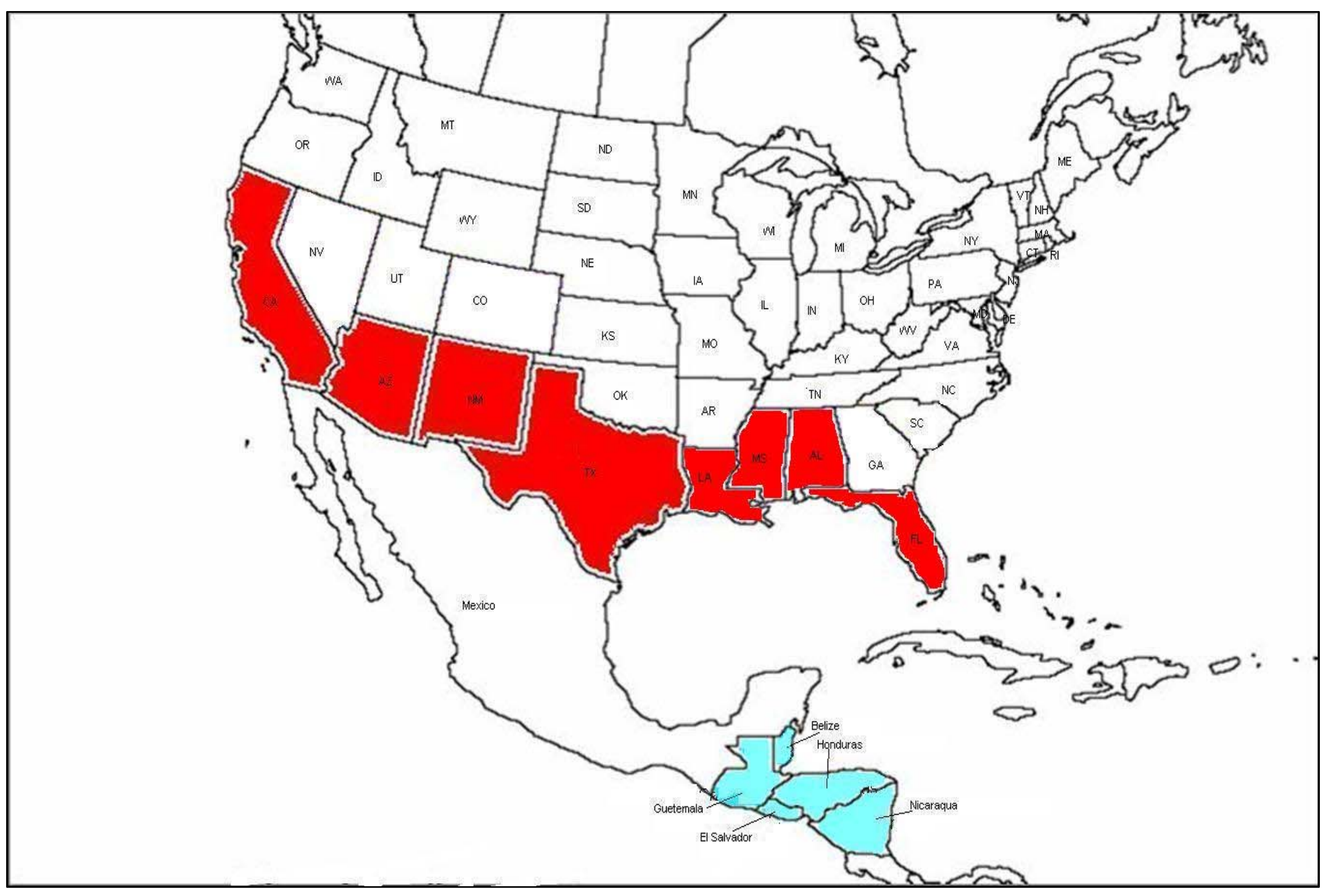

